دراسـة نقديـة ( تحليليـة ) لقـانون الجمعيـات الأهليـة رقم (•V) لسـنةV I • بجمهوريـة مصـر العربيـة

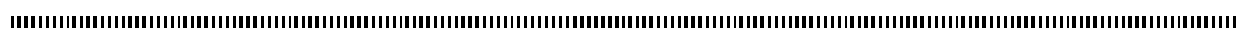

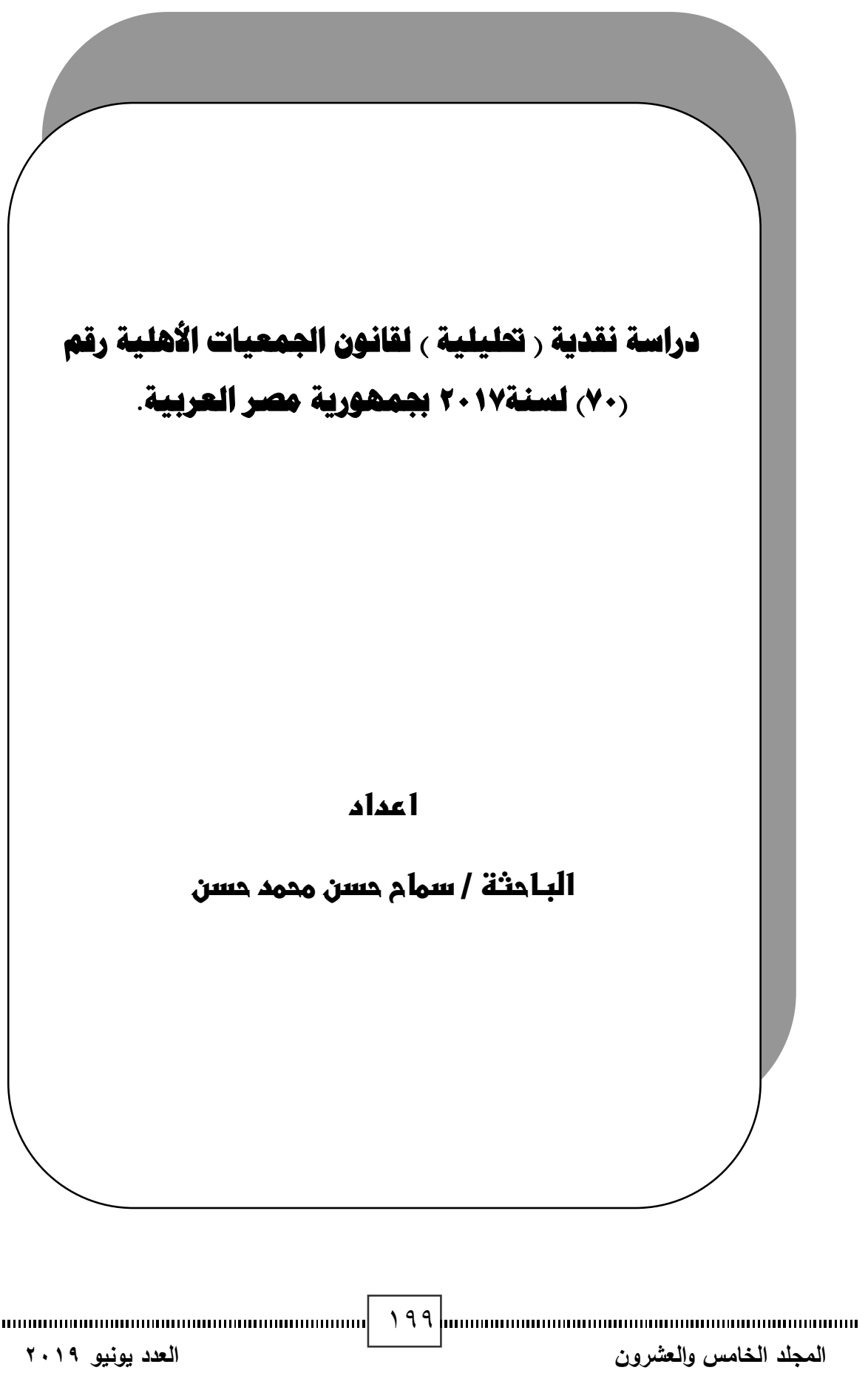


دراسـة نقديـة ( تحليليـة ) لقـانون الجمعيـات الأهليـة رقم (•V) لسـنةV I ـ بجمهوريـة مصـر العربيـة

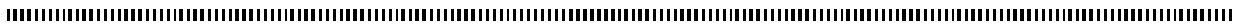




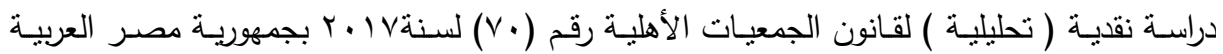

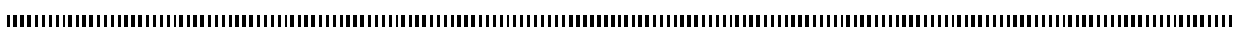

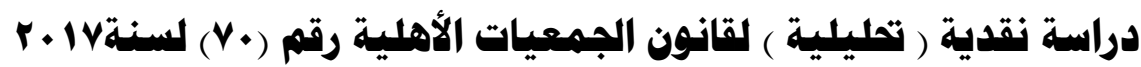
بمههورية هصر العربية.

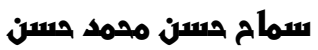

\section{مشكبة الدراسة}

تتلخص مشكلة الدراسة في العبارة الاتية:

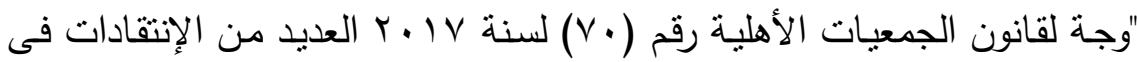

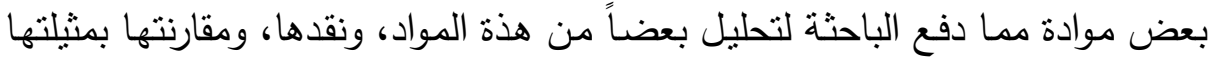
بالقانون السابق ، وذللك وصولا منها لعرض بعض البه التوصيات والمقترحات التى تتفادى دهى بها إنتقادات بعض مواد القانون.

\section{همقدمة}

حظي موضـوع الجمعيـات و المؤسسـات الاهليـة بأهتمـام كبيـر علـي الصـعيدين المحلي و الدولي، وان الاعتراف بمبدأ حرية تكوين الجمعيات و المؤسسات الاهلية هو الهو

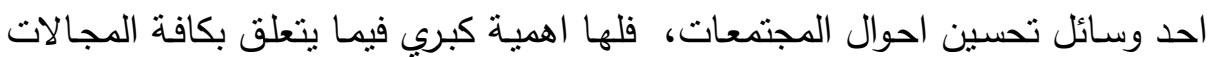

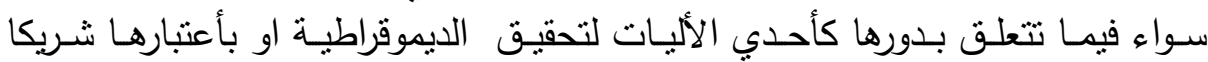
للاولة في عملية التتمية

والنهوض بمجتمعاتها التي تعمل بها، وكذلك دورهـا الكبير و المهم في حمايـة

حقوق المواطنين وحرياتهم (')

نشأت فكرة الجمعيات الاهلية منذ عدة قرون في دول الغرب الرأسمالي، وذلك في اطار مفهوم الخير و الاحسان في ضوء القيم الدينية، و ارتبطت معظم هذوة هذة الجمعيات

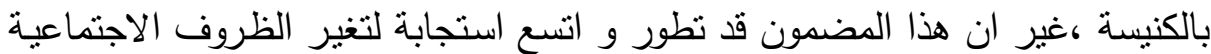

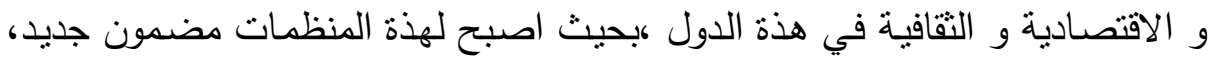
ودور اكثز فاعلية في مجتمعاتها ، و لقد تزايد عدد الجمعيات الاهلية في العقد الاخير

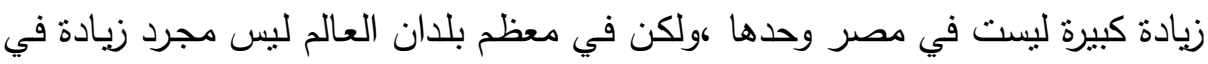
العدد فقط ،ولكن إيضا في النشاط وطبيعة الاغراض و و الاهدة فئ معاف مدا يمكن القول بأنها

شملت مختلف جوانب النشاط الانسان

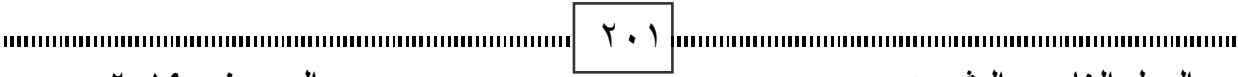
العدد يونيو 9 ب r r المجلد الخامس والعشرون 


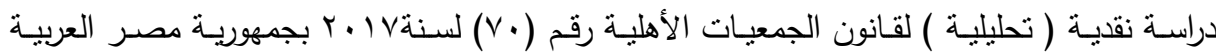

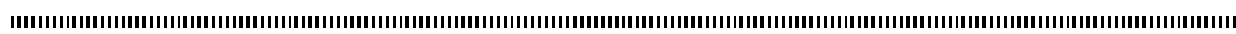
وقد صدرت عدة قوانين منظمة لعمل الجمعيات الاهلية منذ قانون رقم بات لسنة

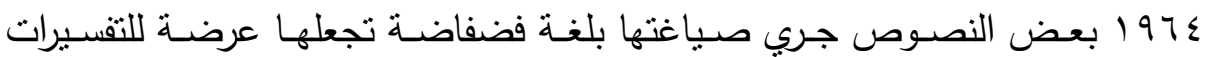

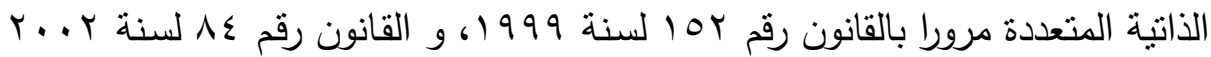

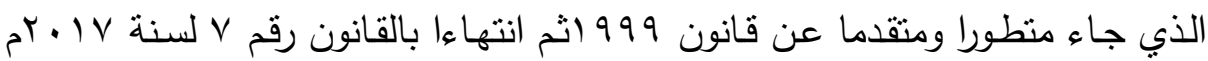

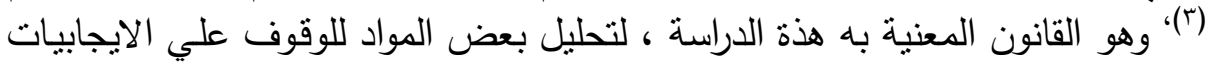
و السلبيات لهذا القانون

\section{هشكلة الدراسة}

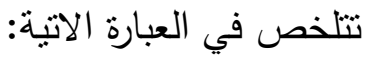

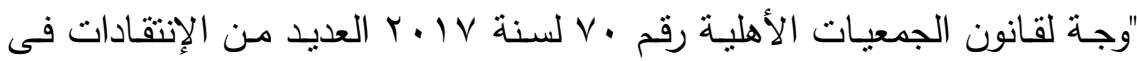

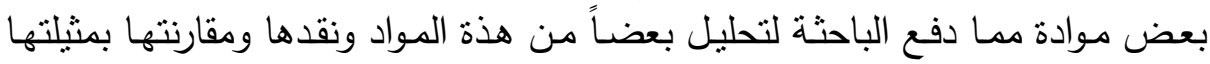
بالقانون السابق ، وذلك وصولا منها لعرض بعض لباد التوصيات والمقترحات التى تتفادى بها إنتقادات بعض مواد القانون

\section{تساؤلات الدراسة : ت ت}

1- ما مفهوم الجمعيات الاهلية وأهدافها وأهميتها فى المجتمع المصرى ؟ ץ- ماالفرق بين الجمعية الأهلية والمؤسسة الأهلية ؟ مأه

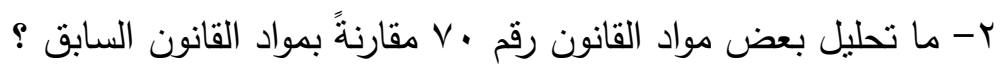
r- ما سلبيات وإيجابيات بعض مواد القانون الجديد ؟

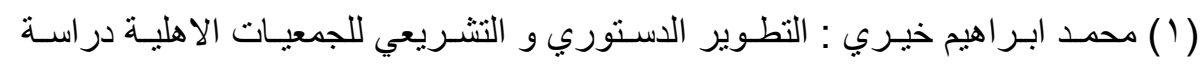

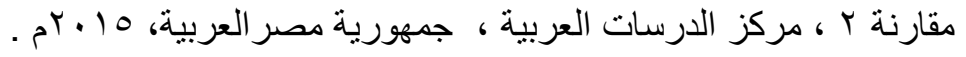

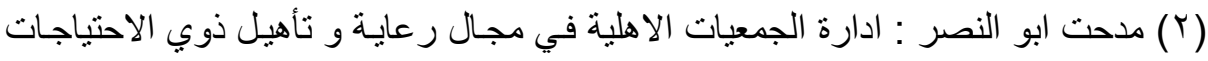

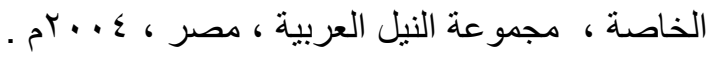

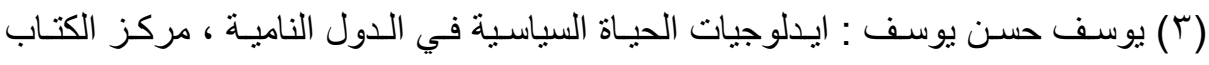

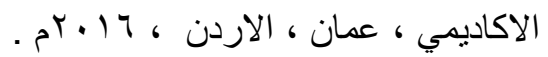

IIII)

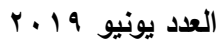
المجلد الخامس والعشرون 


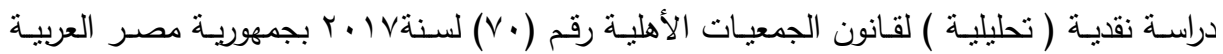

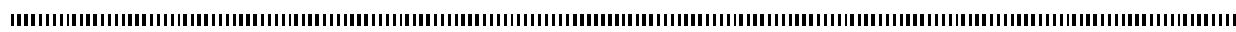
ع - مـا المقترحسات والتوصسيات المقدمـة لتفـادي سـلبيات بعض بنـود قـانون V لسـنة

\section{اهداف الدراسة :}

1- التعرف علي مفهوم الجمعيات الاهلية وأهدافها وأهميتها فى المجتمع المصرى • r- توضيح الفرق بين الجمعية الأهلية والمؤسسة الأهلية .

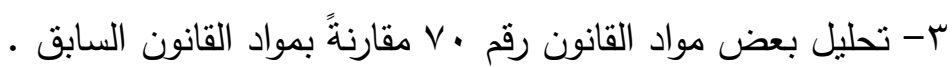
ع- عرض سلبيات وإيجابيات بعض مواد القانون الجديد •

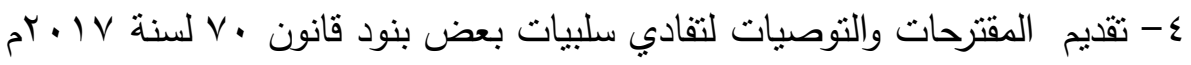

\section{هنهج الدراسة}

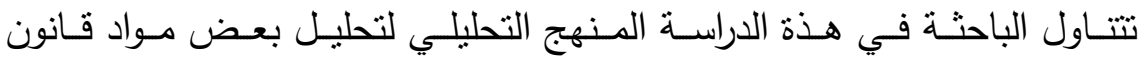

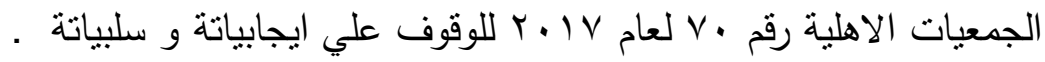

\section{اهميسة الدراستة :}

تكتسب هذة الدراسـة اهميتها من حيث موضوعها، القضية التي تتتاولها فالأهمية

التي تحظي بها الجمعيات الاهلية في المجتمع المصري، و اهمية دورها في التتمية

\section{هدود الدراسة :}

بعض مواد قانون الجمعيات الاهلية رقم · V لسنة IV · م م . تقسم الباحثة هذة الدراسة الي اربع محاور كالأتى:

المحور الأول : مفهوم الجمعيات الأهلية وأهدافها وأهميتها في المجتمـع المصري

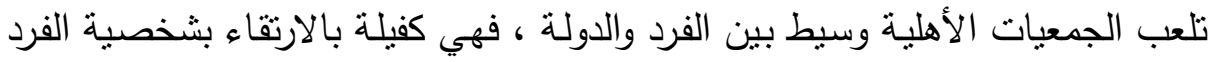

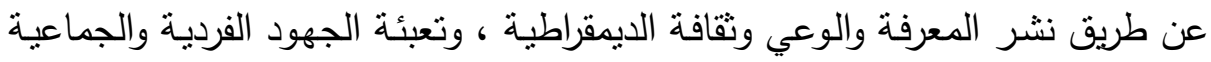

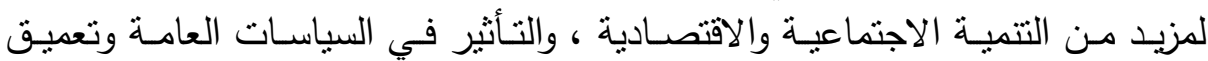
مفهوم التضامن.

وتعود بدايات ظهور المنظمات الأهلية في مصر إلى القرن التاسع عشر ، حيث

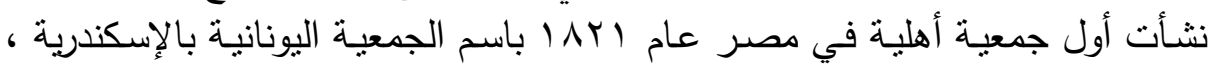

IIII)

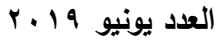
المجلد الخامس والعشرون 
دراسـة نقيـة ( تحليلية ) لقانون الجمعيات الأهليـة رقم (•V) لسنةV ا ب ب بمهوريـة مصر العربيـة

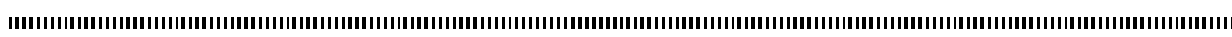

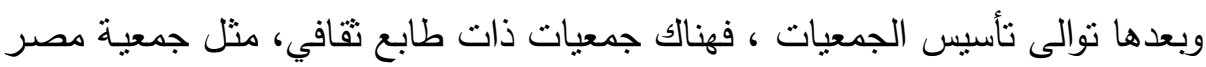

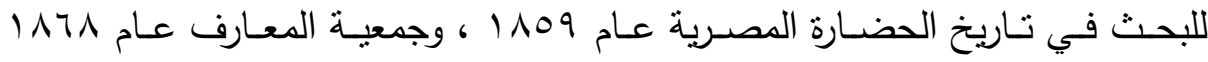

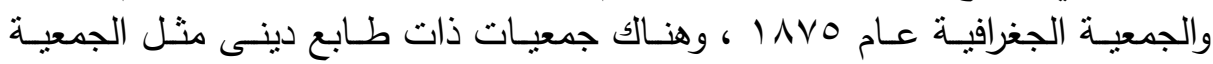

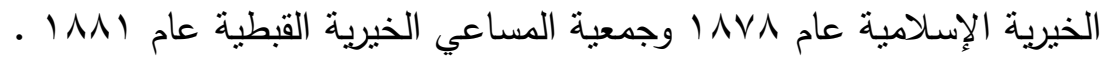

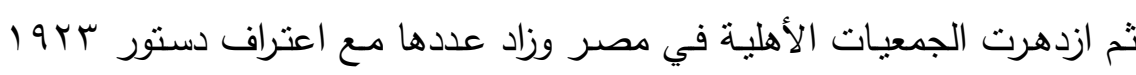

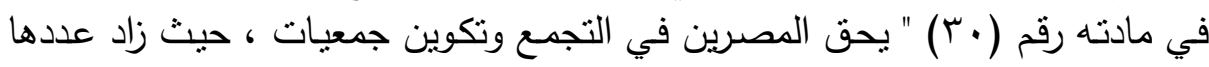

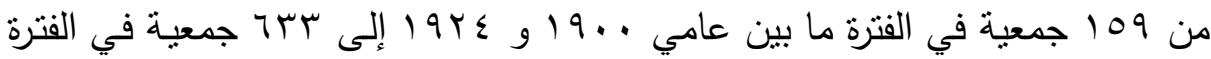
ما بين

منذ منتصف التسععينيات بدأت حركة انتعاش جديدة في المجتمع المدني عموماً

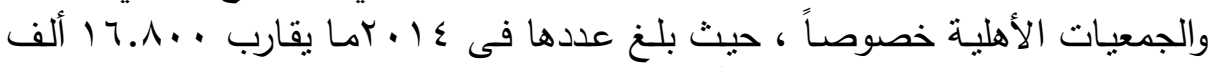

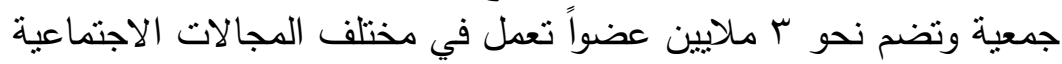

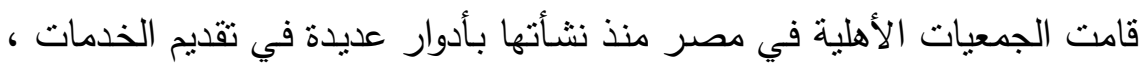

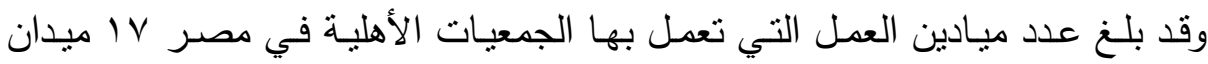
عمل( (1).

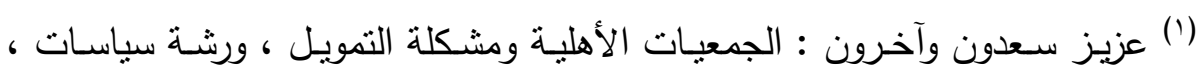

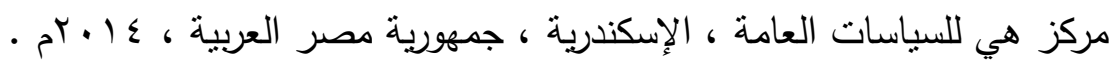

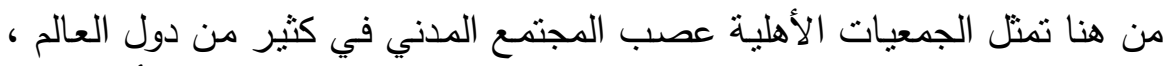



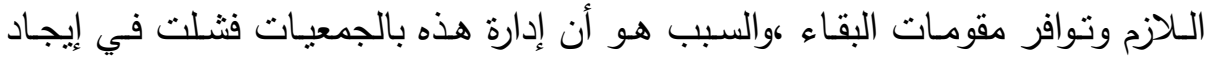

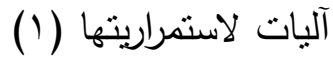



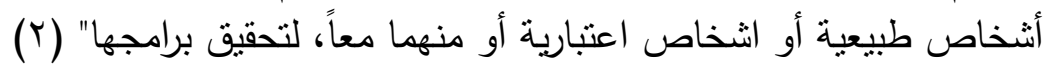

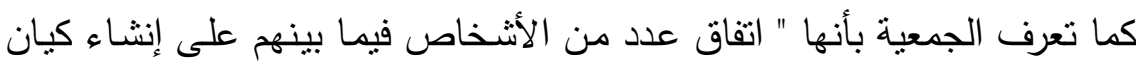


وذلك تحقيقاً لغرض من أغراض البر والتكامل ،أو تحقيق نشاط من هن النشاطات التالية :

ا-ديني ، اجتماعي ، نقافي ، صحي ، تتموي ، توعوي ، تقني .

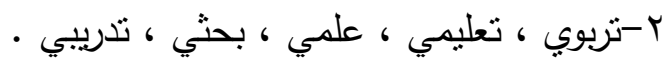

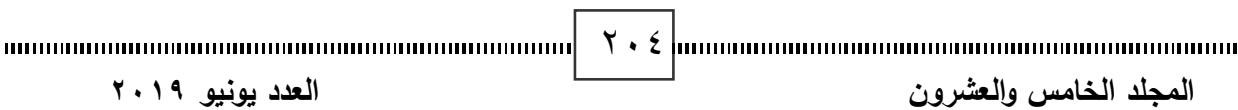
المجلد الخامس والعشرون 


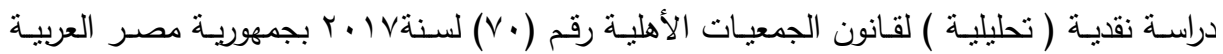

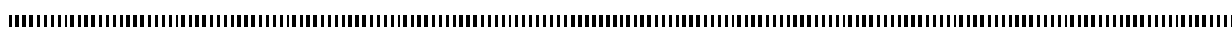

ب-مهني ، حرفي ، شبابي ، نسائي ، سياحي ، تطوعي ·

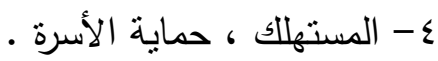

ه-الكوارث ، الأزمات وتحقيق السلامة للمجتمع · ل

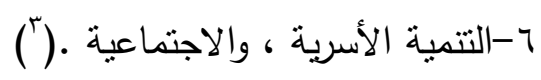

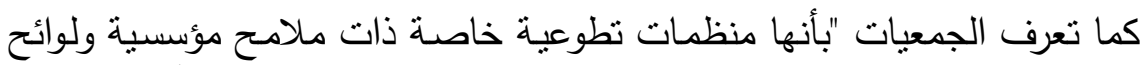

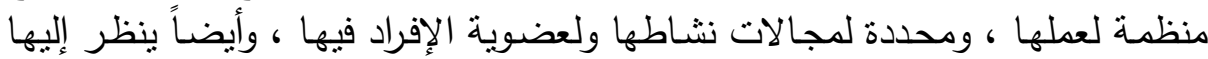

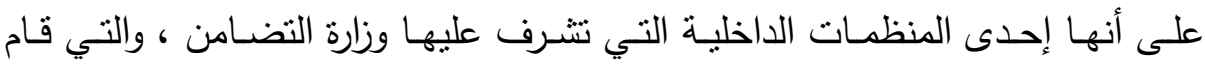

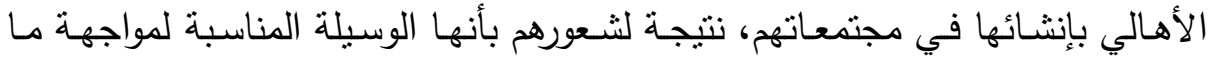

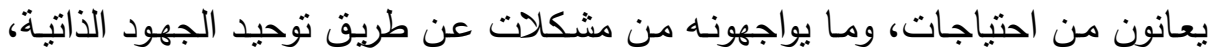
مع جهود المنظمات الحكومية (1). وتأتي أهمية دور الجمعيات الأهلية في التتميـة الاقتصـادية، في الدور التتموي الذي تقوم به باعتبارها الضلع الثالث من منلث التنمية. ونظرا لطبيعة حيز الجمعيات والمؤسسات التي تعتمد على عناصر المجتمع التي

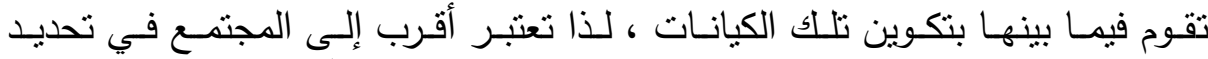

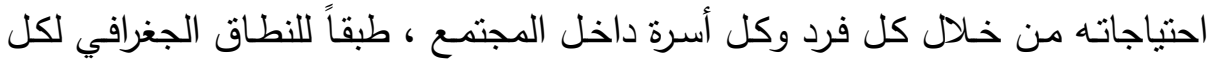

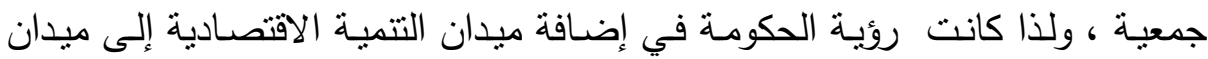

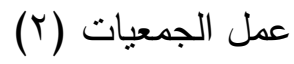

(') محمد الباجوري : تأسيس وإدارة الجمعيات الأهلية / كتاب يخضع لرخصـة الوقت

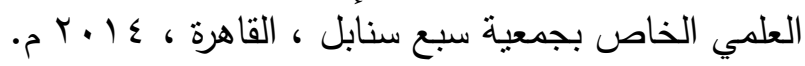

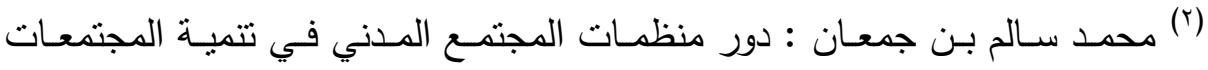

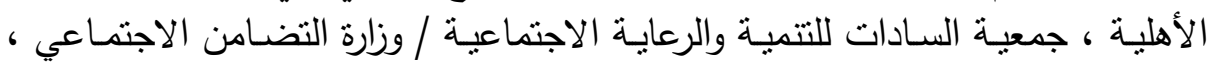

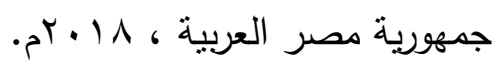

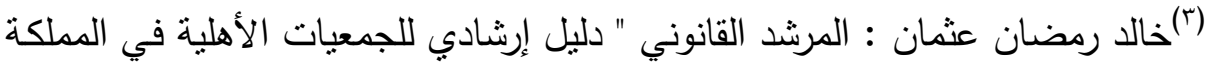

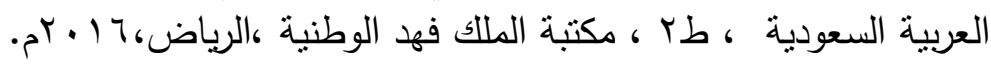

IIIIIIIIIIII)

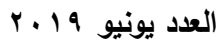
المجلد الخامس والعشرون 


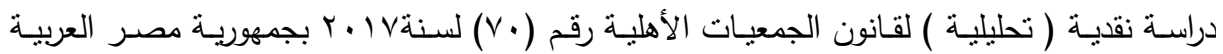

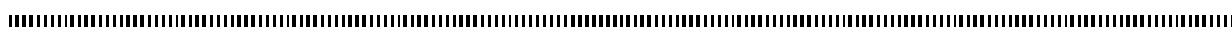
وتستطيع الجمعيات الأهلية في مصر على الرغم مما تعانيه من بعض المعوقات أن تقوم بدور فعال في تتمية المجتمعات المحلية من خلال التخطيط بالمشاركة ، وهو

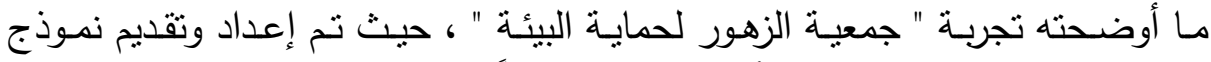

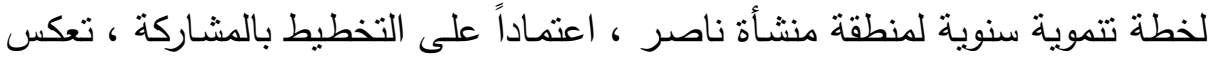

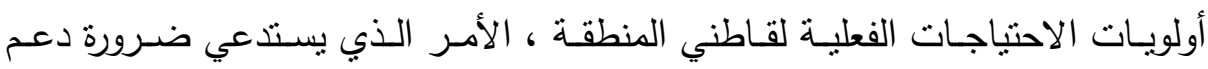



المحسور الثاني : الفرق بين الجمعيـة الأهليـة والمؤسسـة الأهليـة يؤسس الجمعيـة

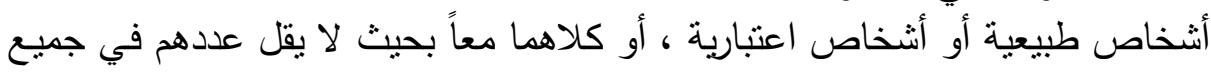

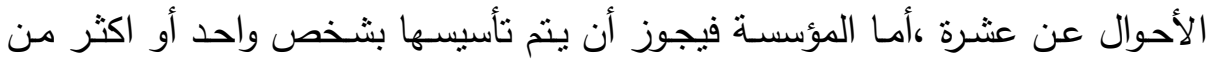





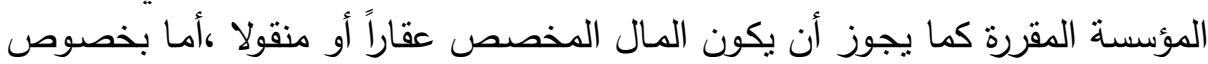
الجمعيات الأهلية، فلا يشترط تخصيص أية أموال لها من قبل المؤسسين أو غيرهم بكون بـون

لإثـهار الجمعية يشترط تقديم طلب إلى إدارة الجمعيات التابع لها مقر الجمعية



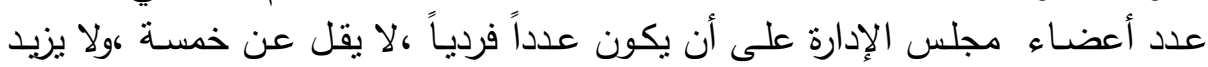

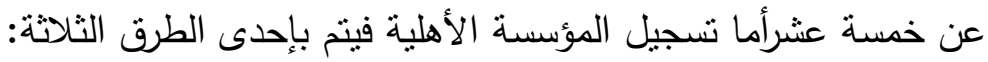

(') طارق حسن صديق : دور الجمعيات الأهلية في تربية الطفل المعوق دراسـة ميدانية

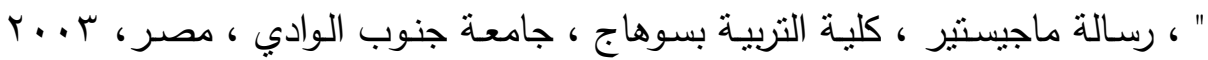

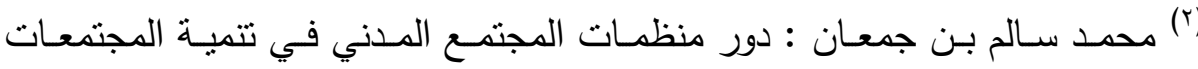

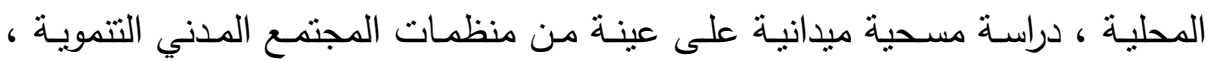

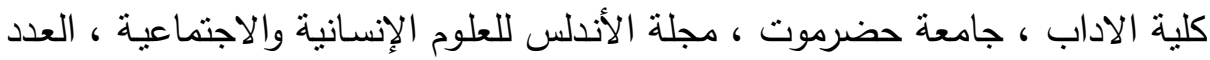

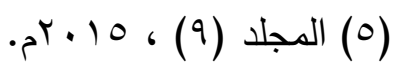

(r) فهمـي محد الخطيـب : دور الجمعيـات الأهليـة في تفعيـل التخطيط بالمشـاركة "

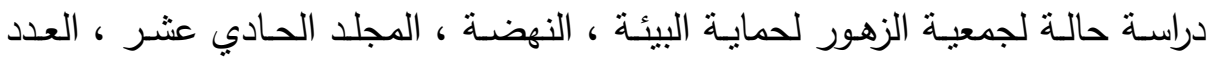

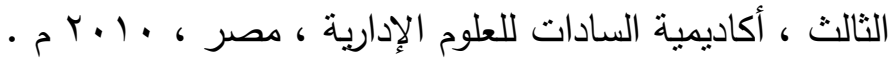

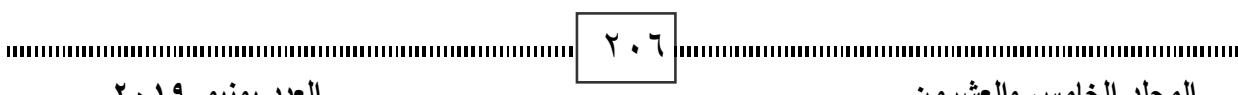

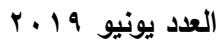
المجلد الخامس والعشرون 
دراسـة نقيـة ( تحليلية ) لقانون الجمعيات الأهليـة رقم (•V) لسنةV ا ب ب بمهوريـة مصر العربيـة

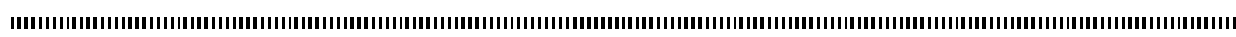
- نظام أساسي يضعه المؤسس أو المؤسسون، مبيناً فيه كل منهم صفته ومحل إقامته

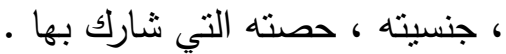

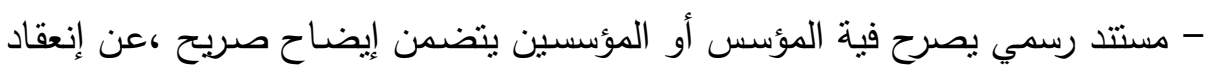

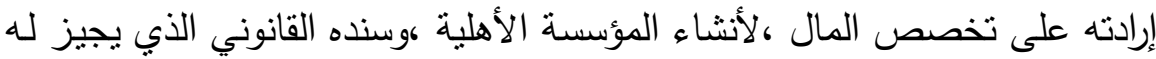

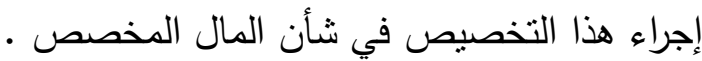

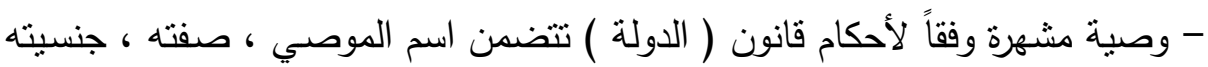

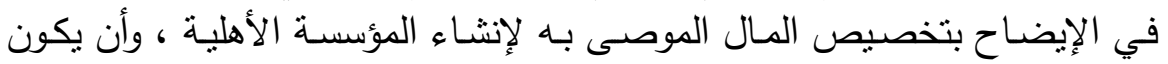
لكل مؤسسة مجلس أمناء يتكون من عدد فردي لا يقل عن ب ولا يزيد عن 10 .

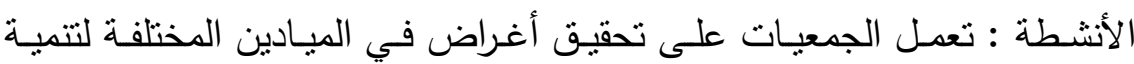

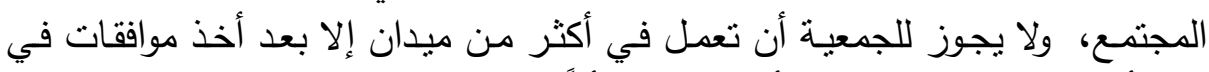




أولا : فيما يخص تأسيس الجمعيات الأهلية وأنشطتها وأغراضها والرقابة عليها

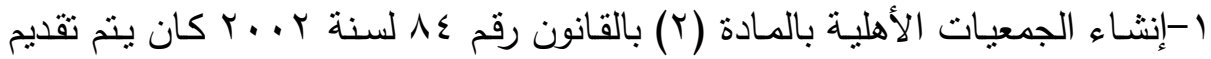

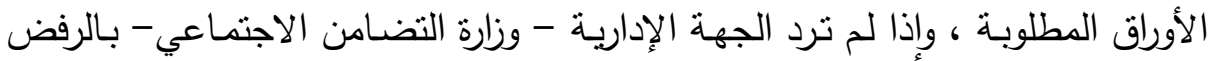

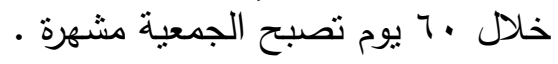

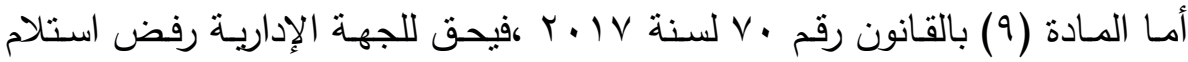

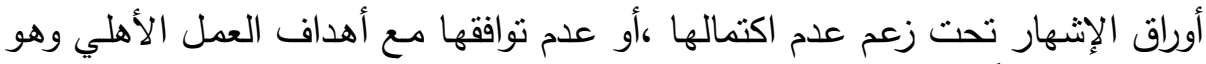

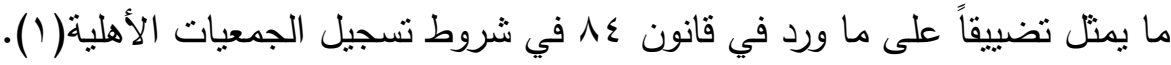

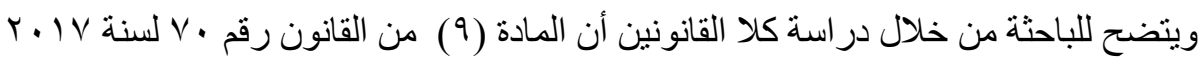

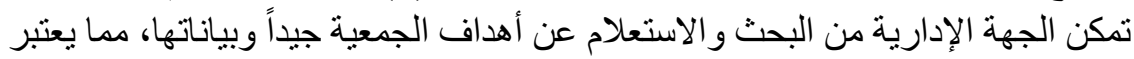



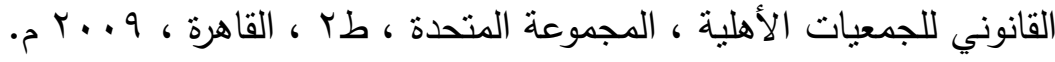

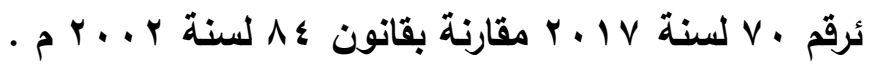

IIII)

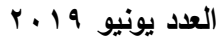
المجلد الخامس والعشرون 
دراسـة نقيـة ( تحليلية ) لقانون الجمعيات الأهليـة رقم (•V) لسنةV ا ب ب بمهوريـة مصر العربيـة

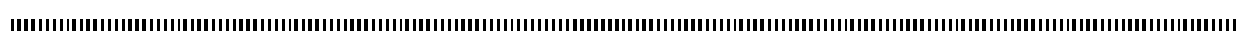

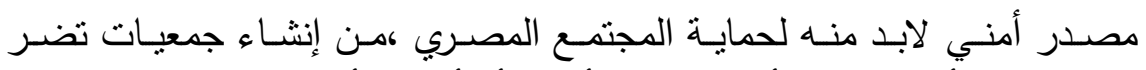

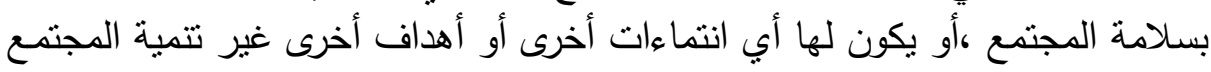

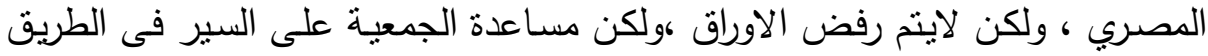
الصحيح وتقيم كل وسائل المشورة لإستكمال الأوراق.

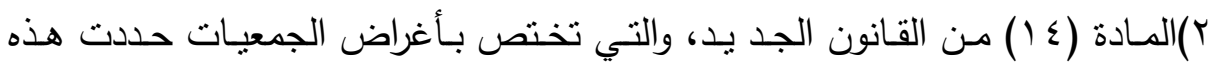

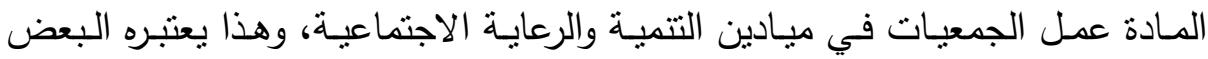

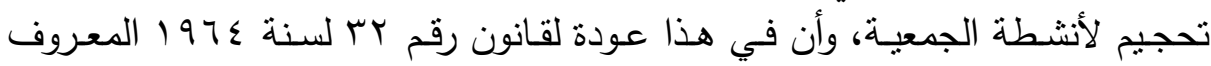
بقانون تأميم العمل الأهلي (r).

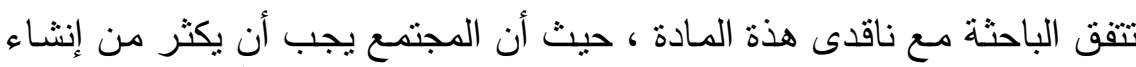

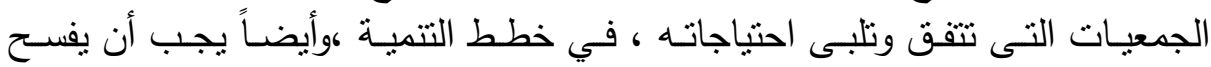

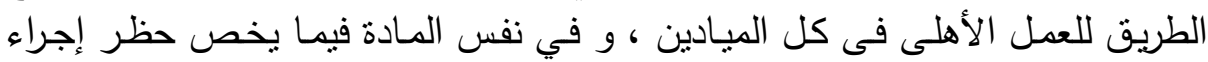

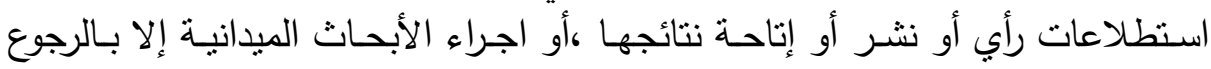

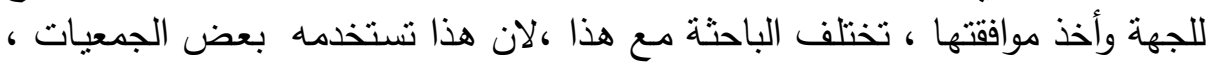

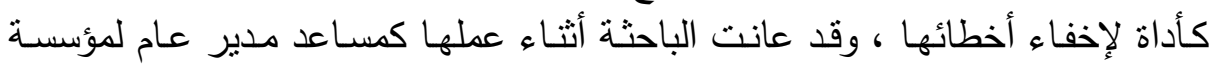

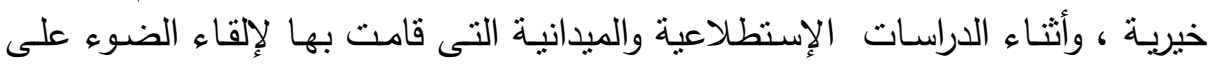

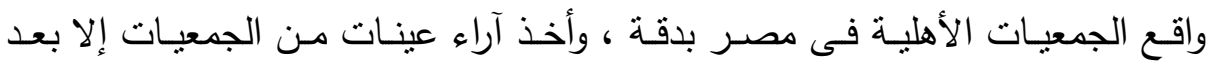

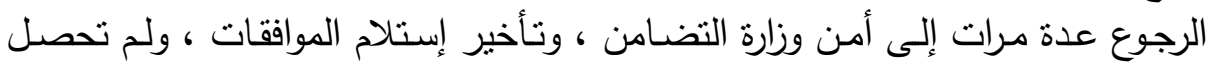

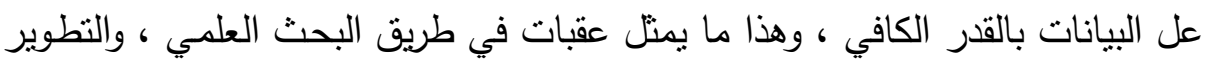

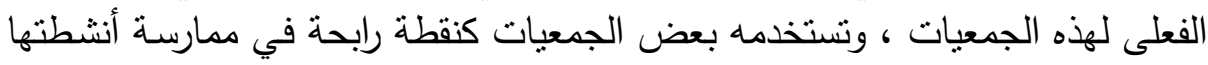

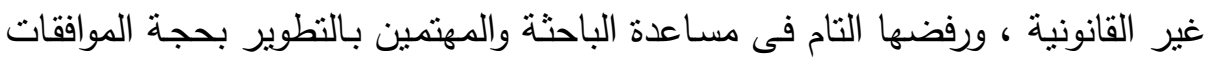

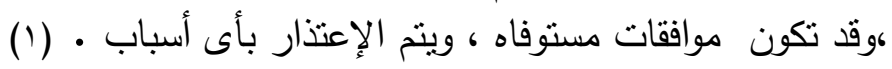

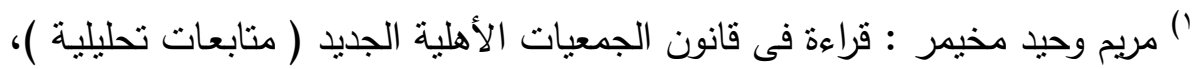

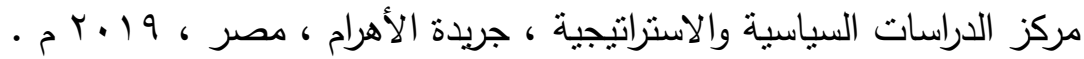

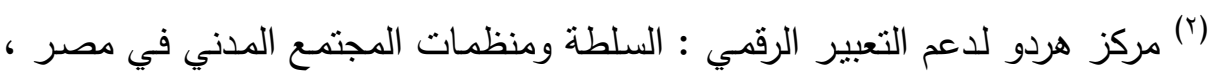

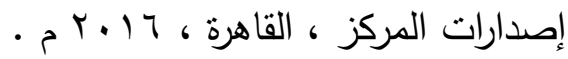

IIII) العدد يونيو 9 1 ـ المجلد الخامس والعشرون 
دراسـة نقيـة ( تحليلية ) لقانون الجمعيات الأهليـة رقم (•V) لسنةV ا ب ب بمهوريـة مصر العربيـة

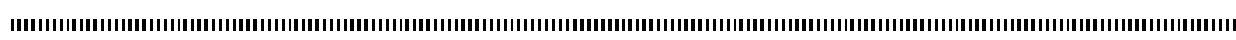

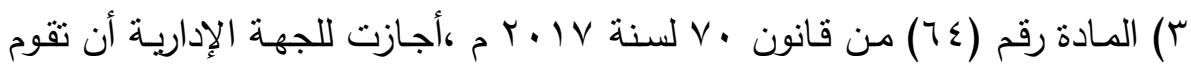

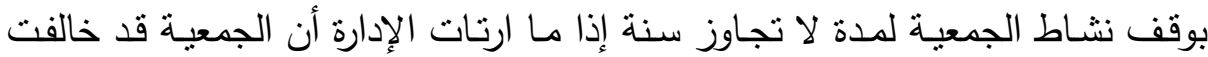

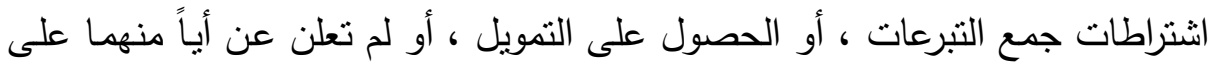

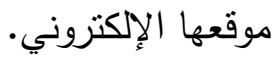

(1) أثناء الدراسـة الميدانيـة لبعض الجمعيات ومن أمثلتها جمعية أولادى بنات وأولاد

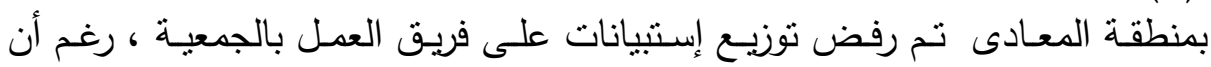

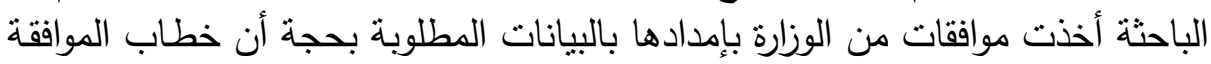

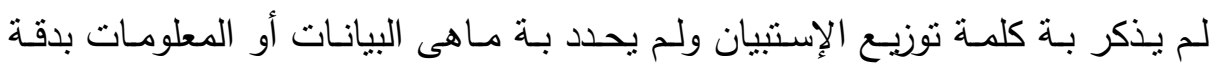

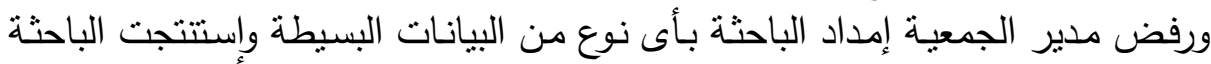



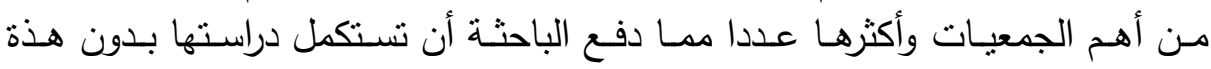

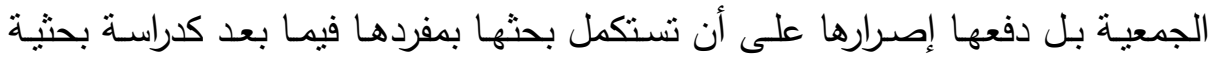

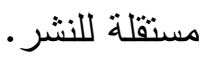

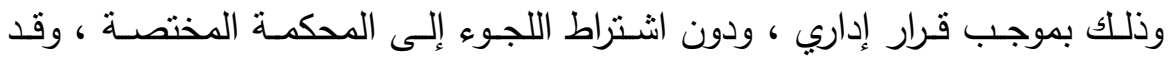

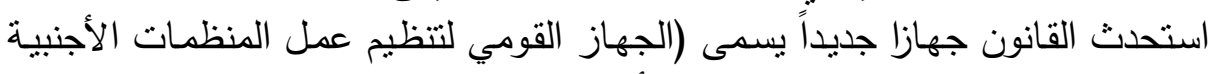

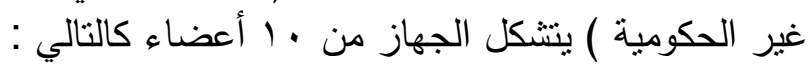

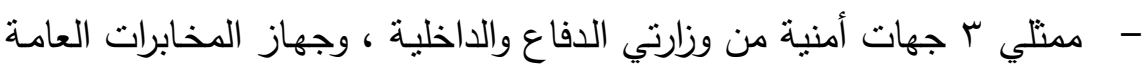

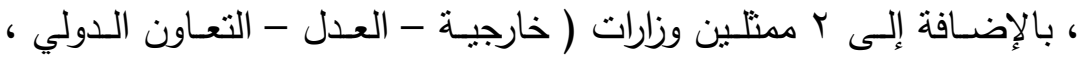

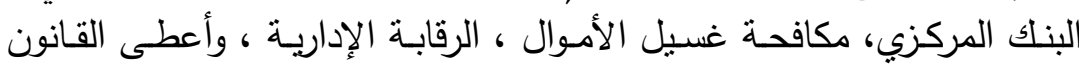

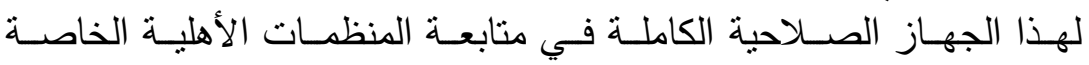
والإشراف عليها (1).

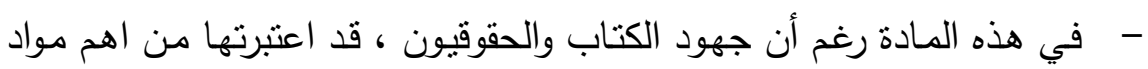

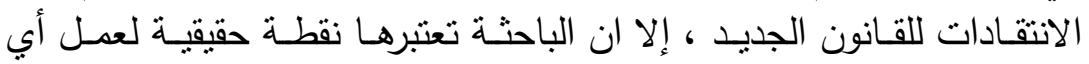

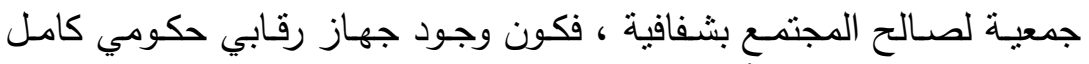



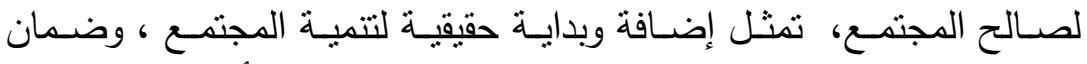

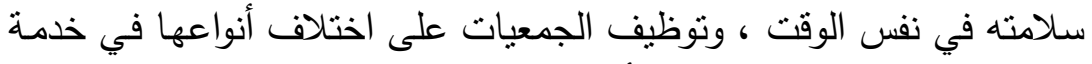

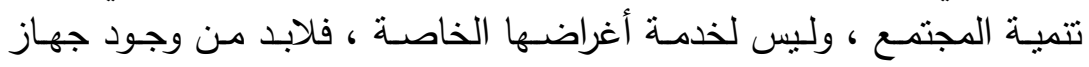

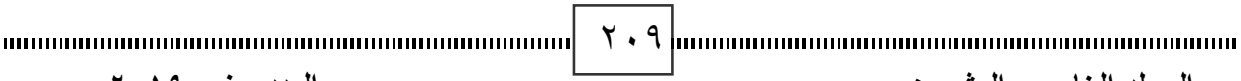

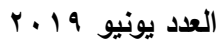
المجلد الخامس والعشرون 
دراسـة نقيـة ( تحليلية ) لقانون الجمعيات الأهليـة رقم (•V) لسنةV ا ب ب بمهوريـة مصر العربيـة

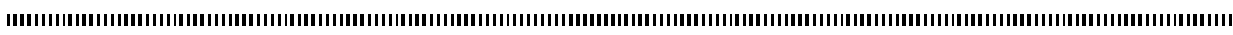
رقابي، ومتابع على هذا المستوى لضـمان أمسن وسـلامة المجتمـع ، وهذا سيحمي المجتمع فيما بعد من تحديات كثيرة قد تقابله .

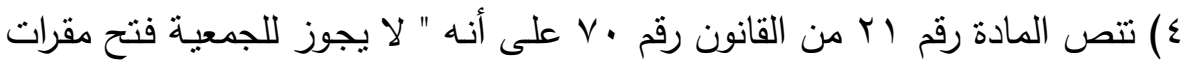

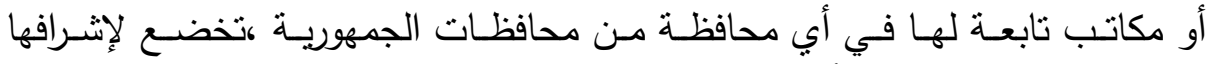

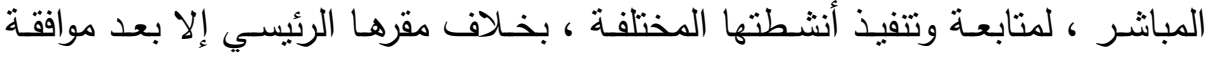

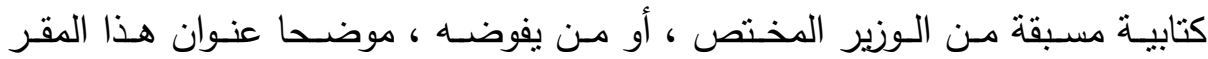

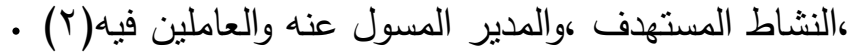

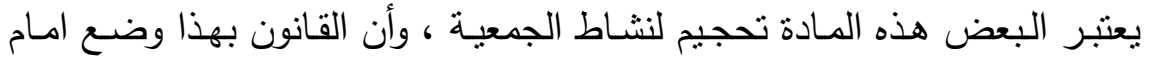

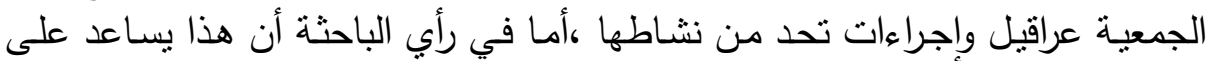

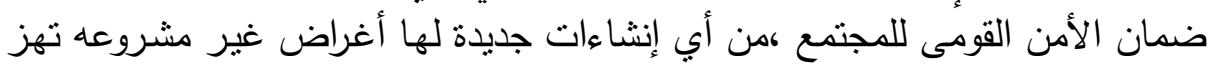

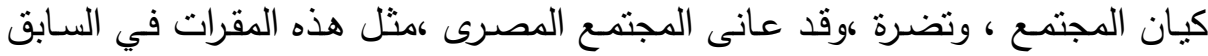

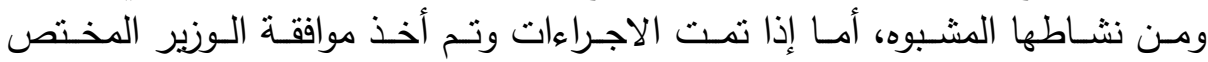

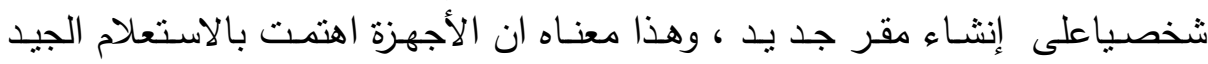

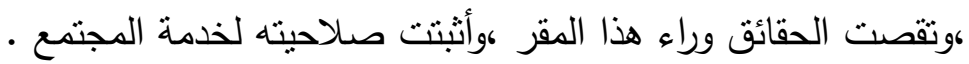
ثانياً : فيما يخص تمويل الجمعيات الأهلية ، والعقوبات التي نوقع على من يخالف

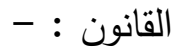

تتص المادة رقم (ع ب) من قانون • V أنه لابد للجمعية الأهلية ، أن تخطر الإدارة

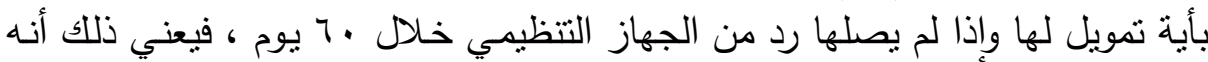

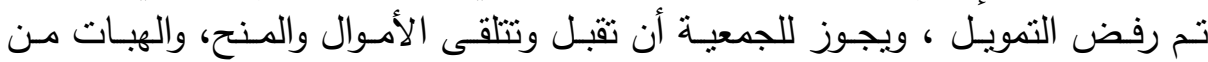

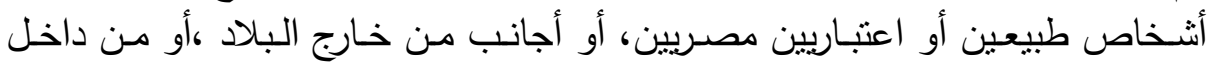

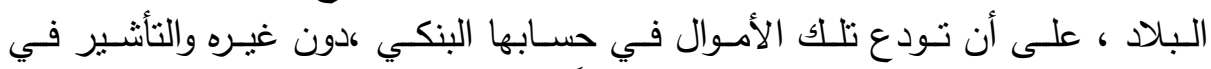
سجلاتها بذلك ، ويصدر الوزير المختص قراراً ينظم إجراءات وقواعد تلقي تلكي الك الأموال

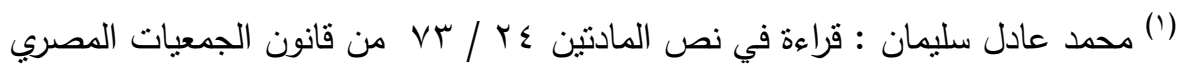
HTTP/WWW.LEGAL-AGENDS.COM,2017

مريم وحيد مخيمر : قراءات في قانون الجمعيات الأهلية الجيد ، مرجع سابق ، ص ؟ .

بعد أخذ رأي الجهاز ، وذللك في خلال ثالاثين يوم عمل من تلقي الأموال، ودخولها

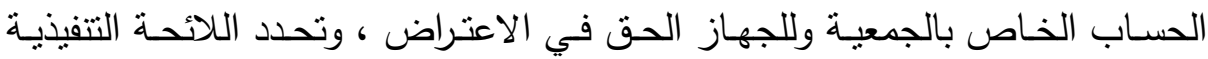

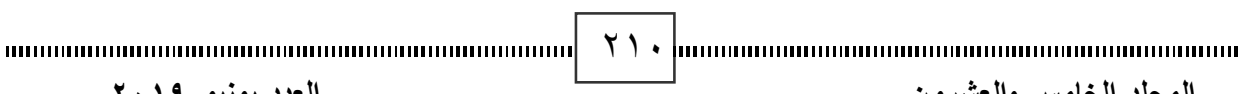

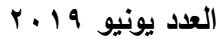
المجلد الخامس والعشرون 
دراسـة نقيـة ( تحليلية ) لقانون الجمعيات الأهليـة رقم (•V) لسنةV ا ب ب بمهوريـة مصر العربيـة

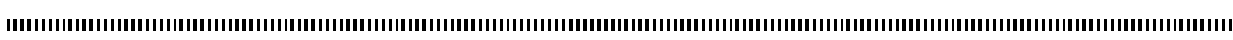
إجراءات وقواعد تلقي الأموال والآثار المترتبة على عدم الموافقة ،وإجراءات الإخطار

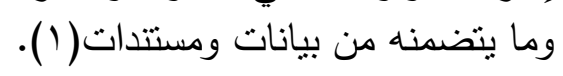

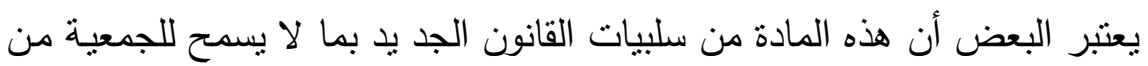

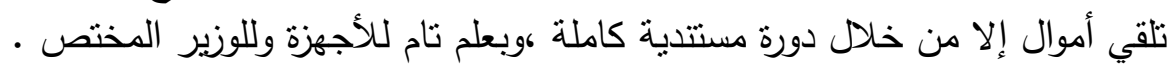



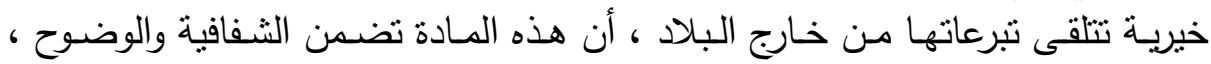

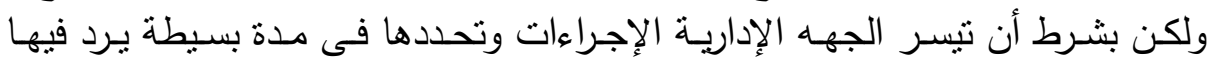

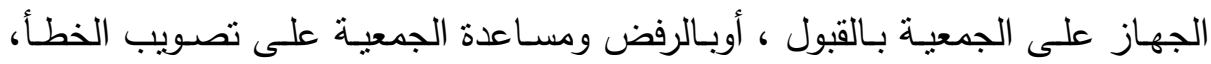
بسرعة حتى لا يتم تعطيل أعمال الجمعية.

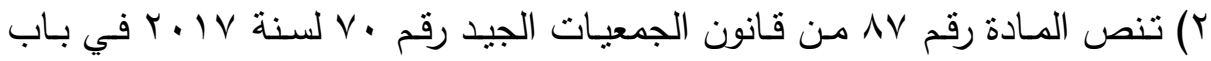

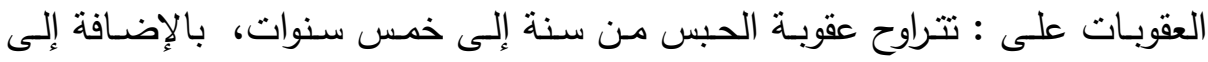

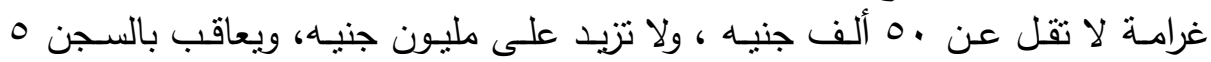

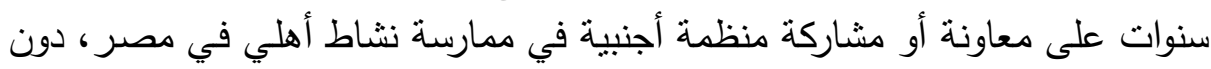


رأي في مجال العمل الأهلي، دون الحراء أحصول على موافقة مسبقة

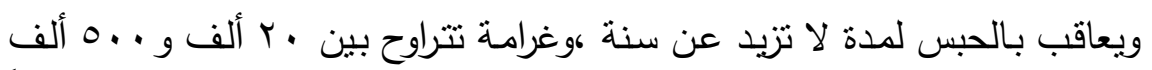

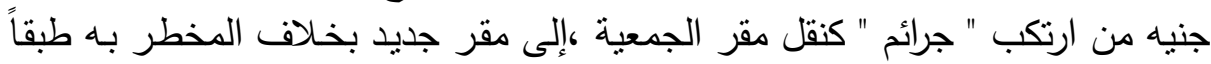

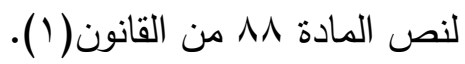

تزيد عن ألف جنيه ،كل من باشر نشاط من أنشطة الجمعية قبل إتمام قيدها وكل من أنثأ مقر للجمعية دون علم الجهة الإدارية .

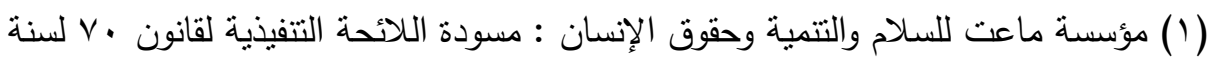

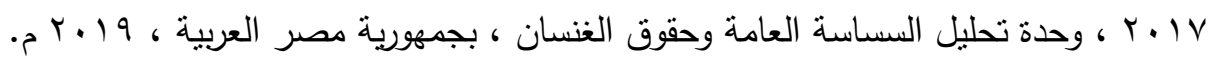

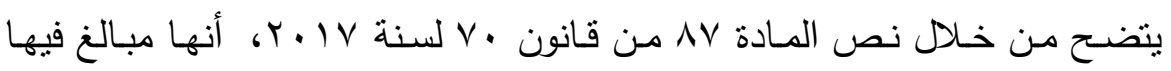

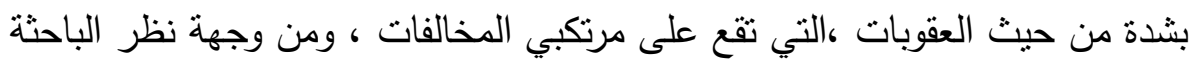




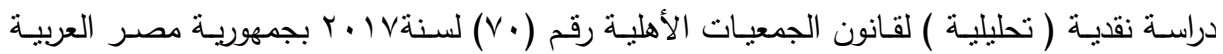

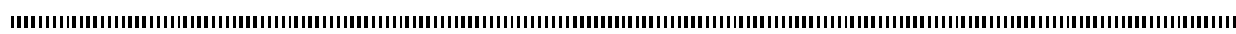

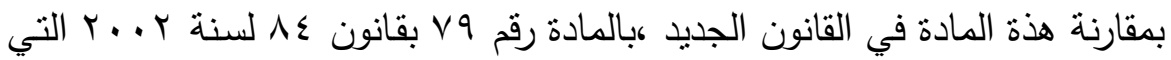

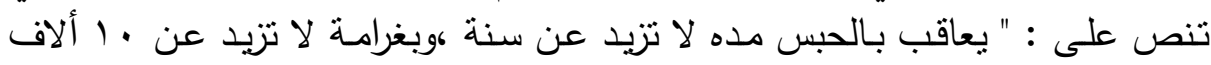

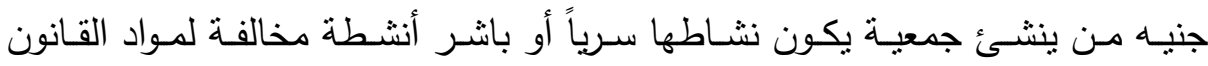

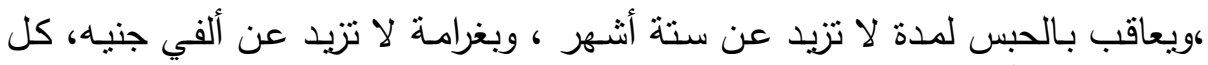

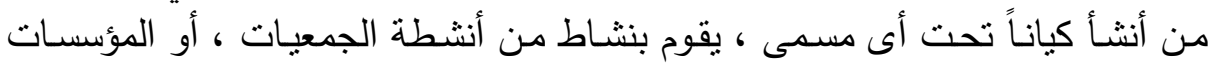

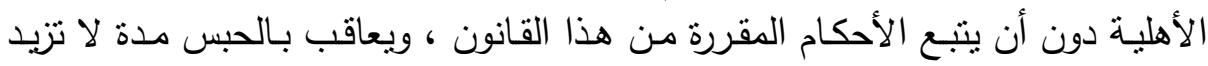

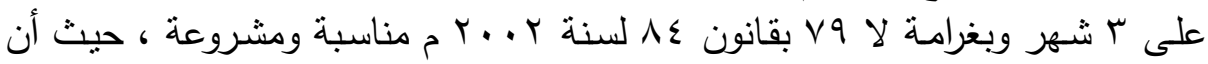

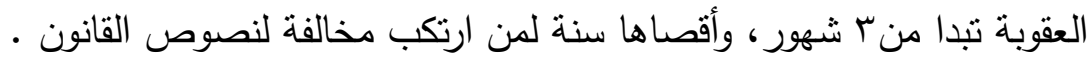

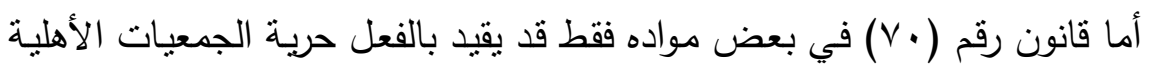

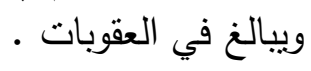

المحور الرابع :ايجابيات و سلبيات بعض مواد قانون الجمعيات الاهلية الجديد رقم

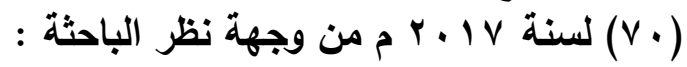
ايجابيات :

1- ان الجمعيـات الاهليـة شـريك اساسـي في عمليـة التتميـة المستـدامة مـع استخدام ادوات رقابية مختلفة.

r- ينص القانون الجديد علي انشاء هيئة وطنية ،تضم ممتلين عن الاجهزة الامنية و

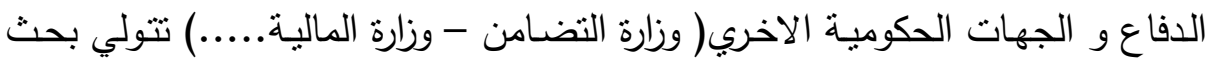

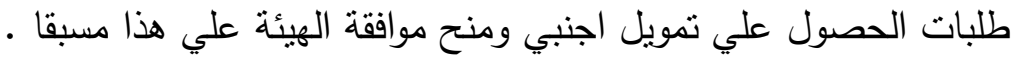

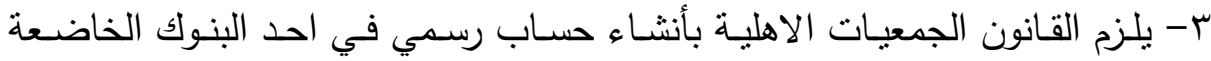

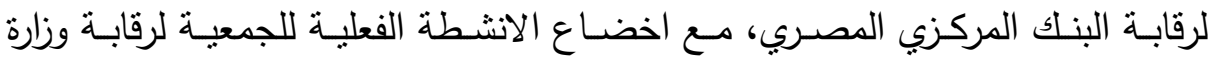



(1) مركز هردو لاعم التعبير الرقمي : السلطة ومنطلبات المجتمع المدني في مصر ، مرجع سابق ، صو هرد .

ع - نص القانون علي اسناد القرار بحل الجمعية يكون للقضـاء وليس من خلال وزارة التضامن المجلا الخامس والعشرون 


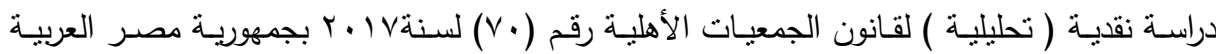

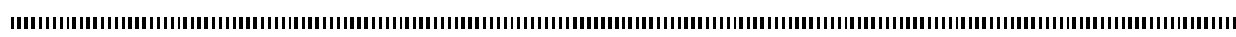

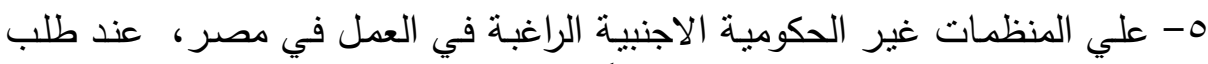

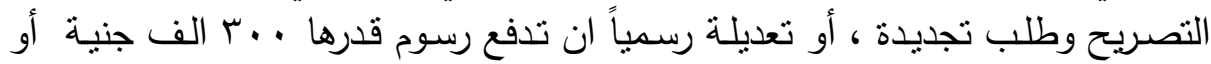

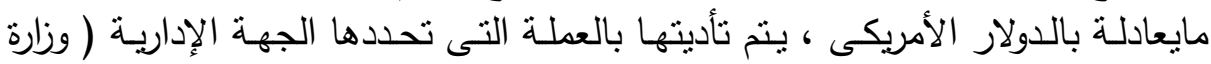



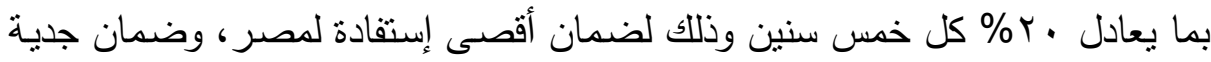
المنظمة الأجنبية.

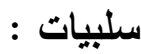

1- تتص المادة N1 من القانون الجديد ،ان يعاقب بالحبس الذي لا تزيد مدة عن سنة

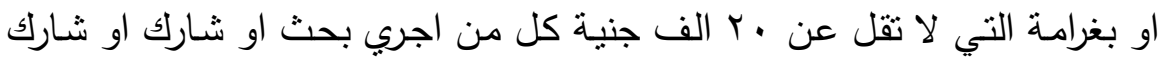

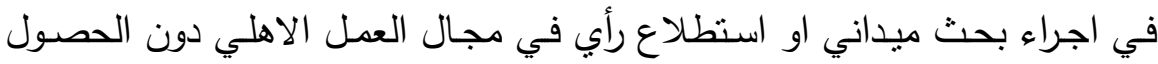
علي موافقات الجهات المعنية قبل اجرائها

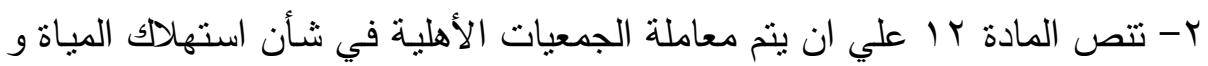

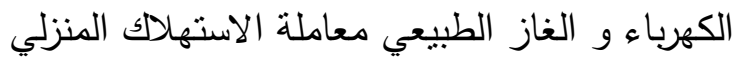
ب- يحظر القانون الجديد علي اي باحث اجراء اي دراسة او اي استطلاع رأي دون

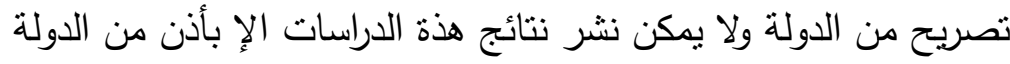

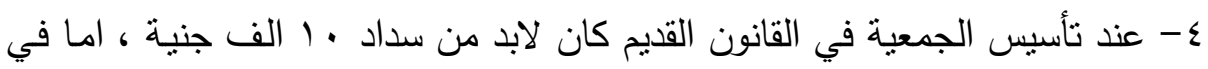

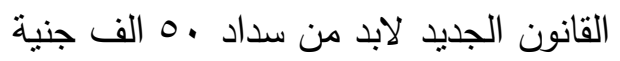

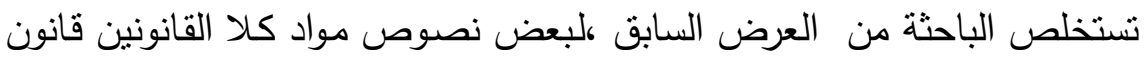

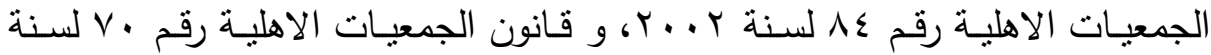

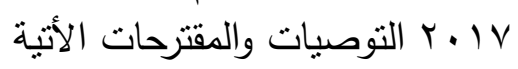

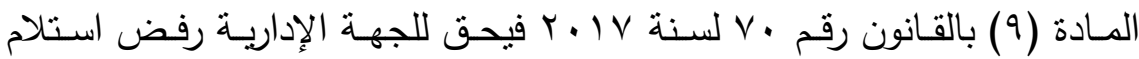

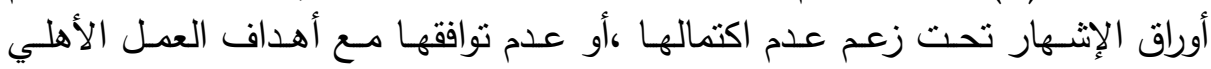

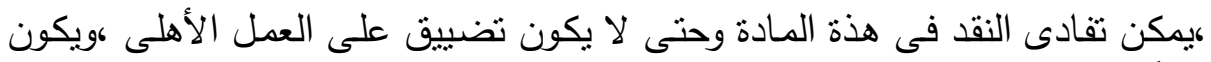

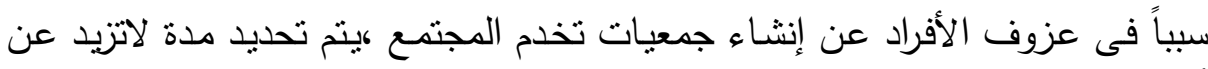

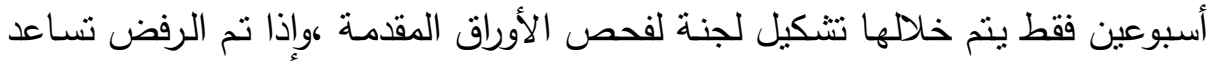

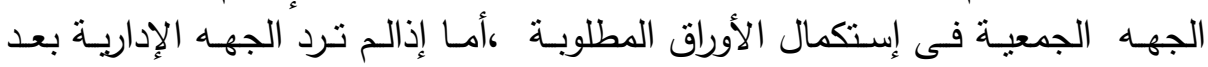
الأسبوعين تصبح الجمعية مشهرة إلينال الأورة 
دراسـة نقيـة ( تحليلية ) لقانون الجمعيات الأهليـة رقم (•V) لسنةV ا ب ب بمهوريـة مصر العربيـة

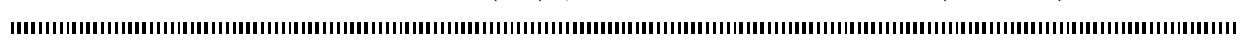

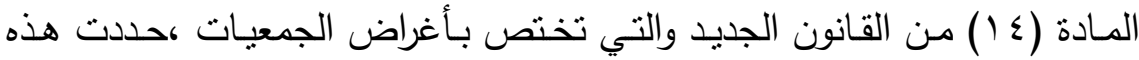

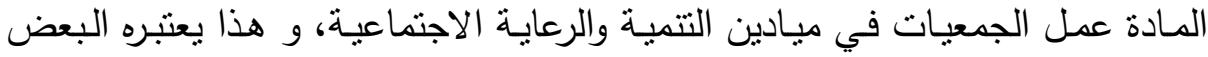

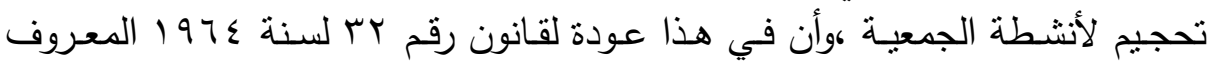

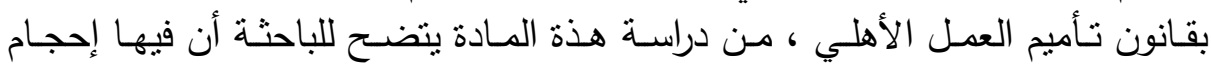

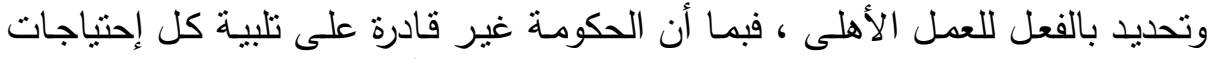

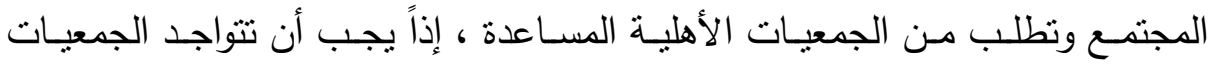

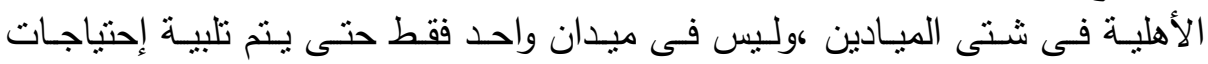

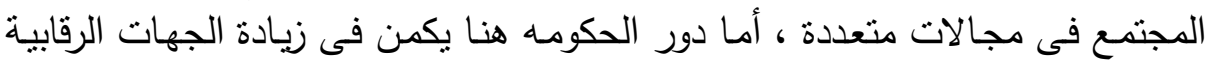

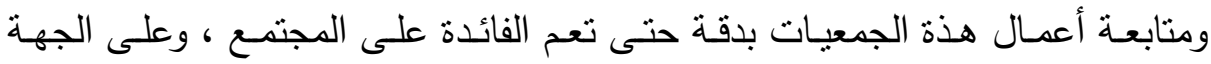
الإدارية أن تتجع إنشاء جمعيات متعددة في ميادين مختلفة.

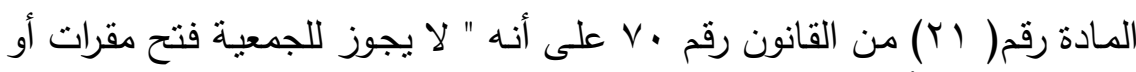

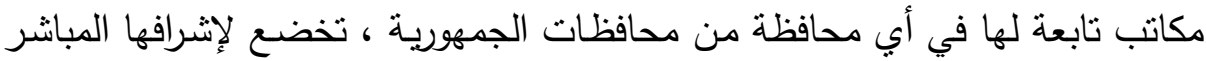

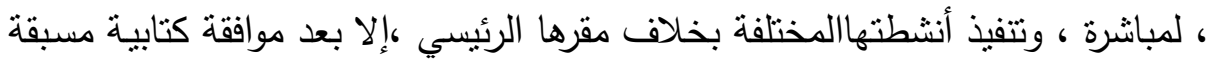

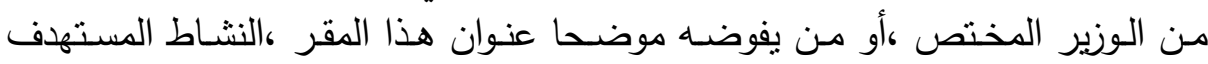

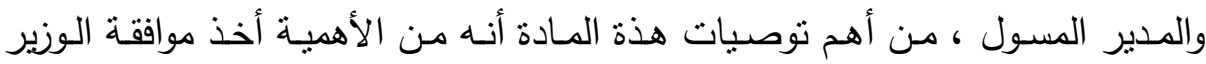

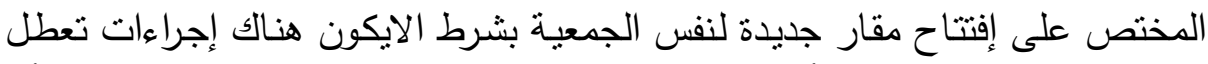



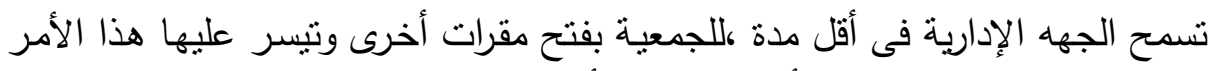

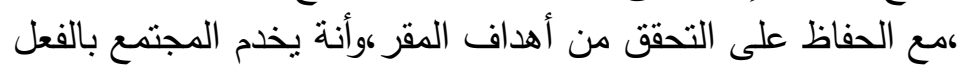

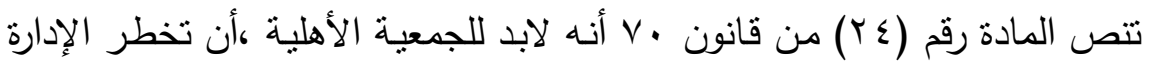

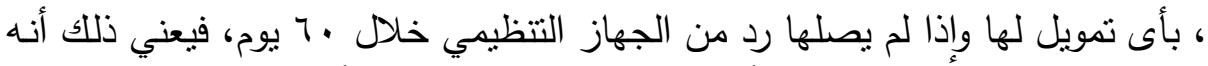

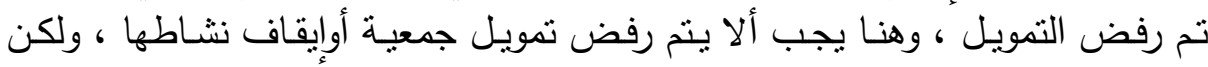

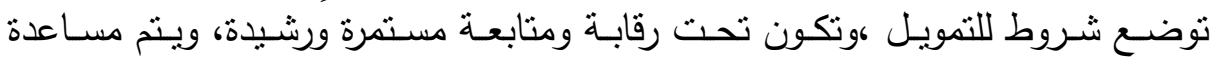
الجمعية على تصويب الخطأ إن وجد. لوند

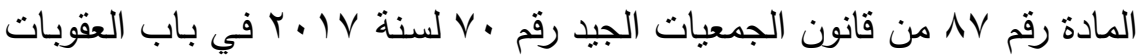



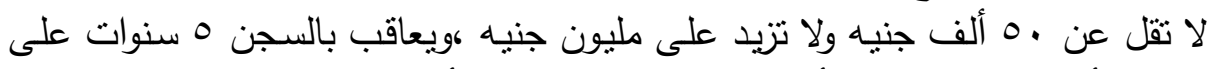

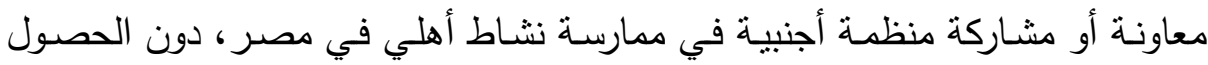
على تصريح أو إجراء أو المشاركة في اجراء بحوث ميدانية أو استطلاعات رأي في أسي 
دراسـة نقيـة ( تحليلية ) لقانون الجمعيات الأهليـة رقم (•V) لسنةV ا ب ب بمهوريـة مصر العربيـة

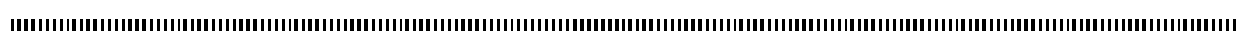
مجال العمل الأهلي دون الحصول على موافقة مسبقة ويعاقب بالحبس لمدة لا تزيد

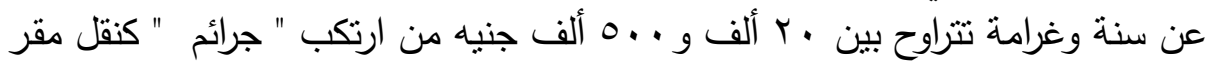

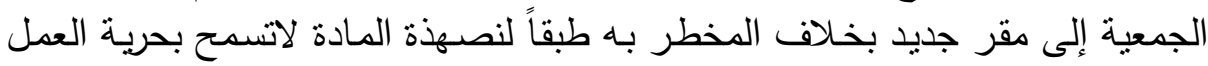

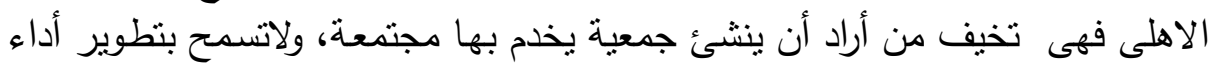



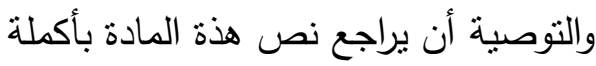

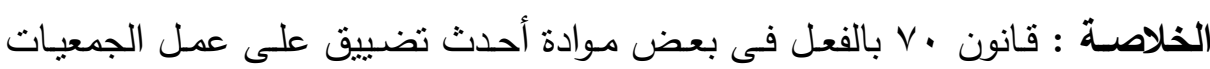

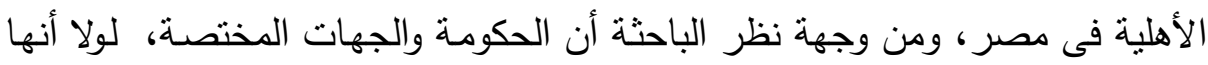

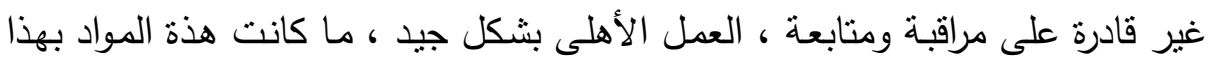

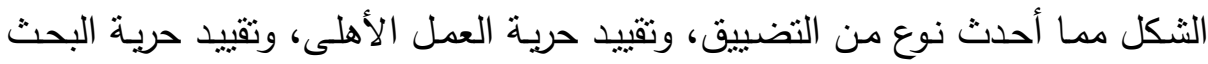

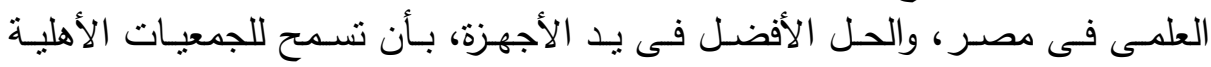

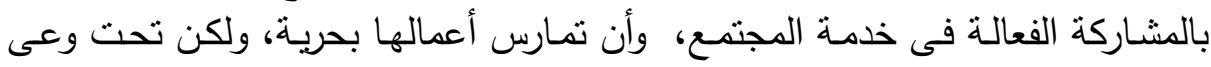

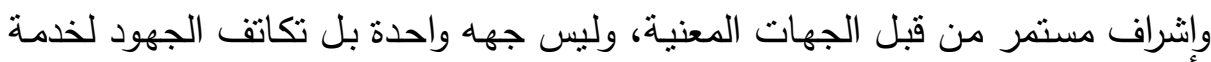

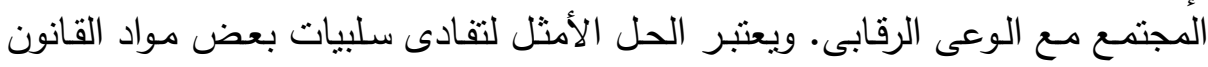

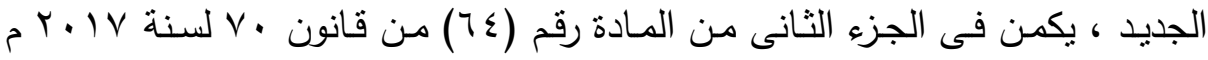

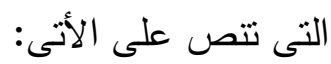
- الاو هو، "قد استحدث القانون جهازا جديداً يسمى (الجهاز القومي لتتظيم عمل التهل

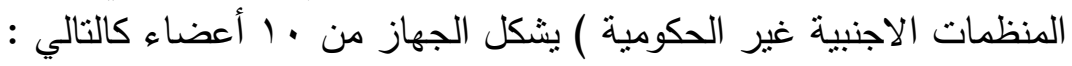

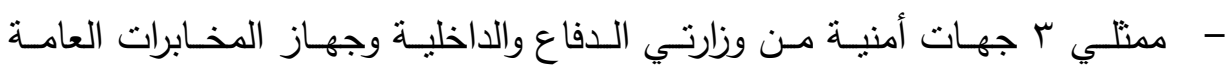

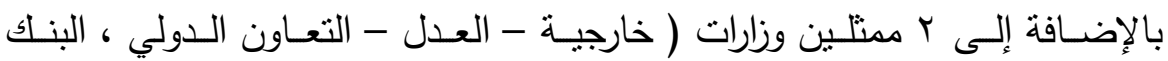

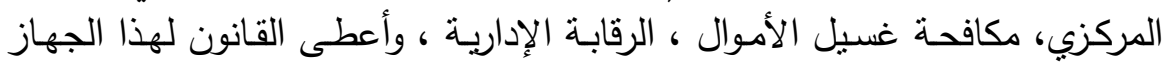



\section{المراجع}




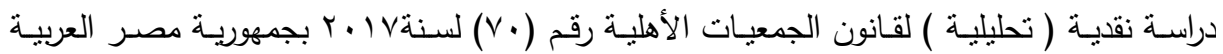

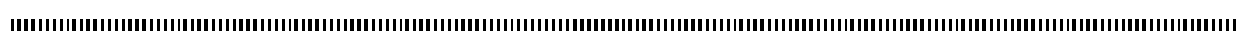

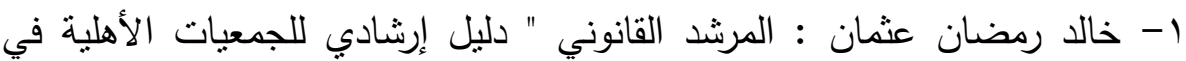

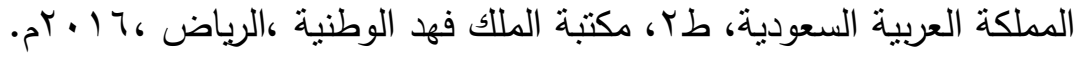

r- طارق حسن صديق : دور الجمعيات الأهلية في تربية الطفل المعوق دراسة

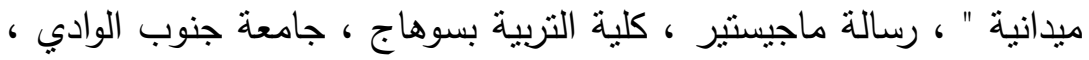



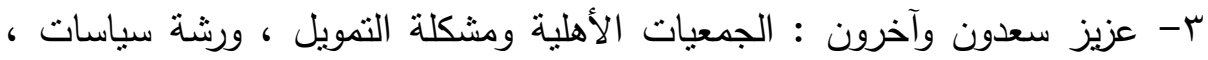

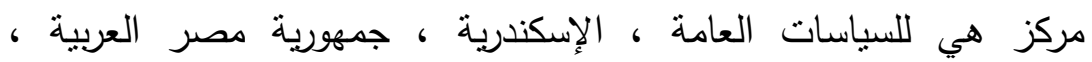

$$
\text { . }
$$

ع - فهمي محمد الخطيب : دور الجمعيات الأهلية في تفعيل التخطيط بالمشاركة "

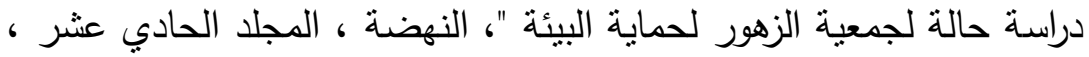

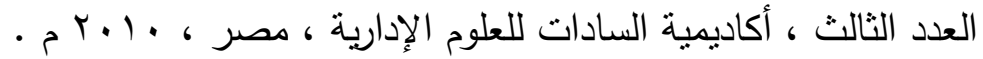

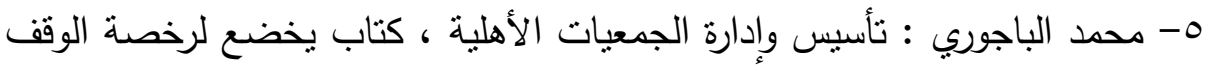

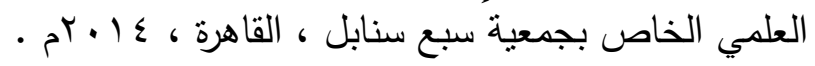

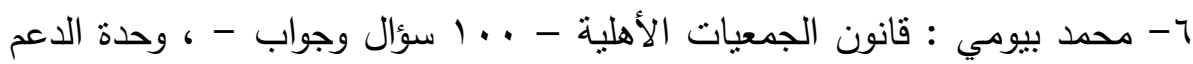



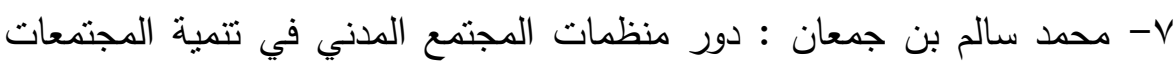

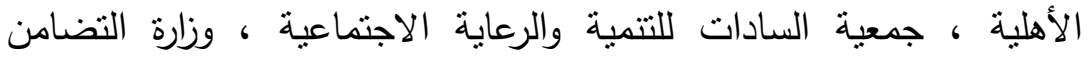



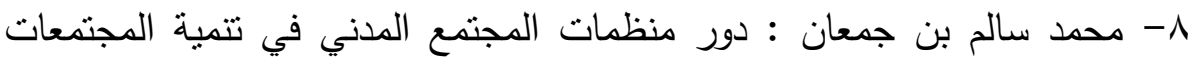

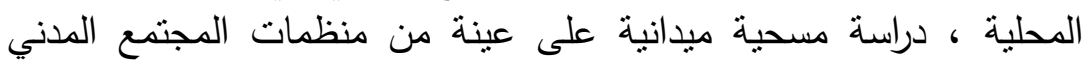

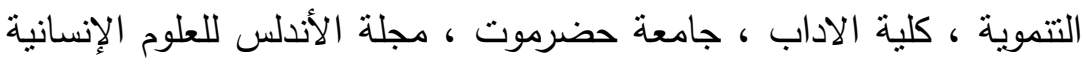

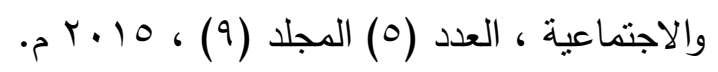

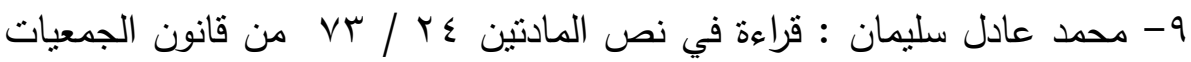

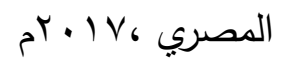

http:llwww.legal-agenda.com

10- مركز هردو لدعم التعبير الرقمي : السلطة ومنظمات المجتمع المدني في مصر

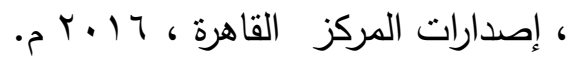


دراسـة نقديـة ( تحليليـة ) لقـانون الجمعيـات الأهليـة رقم (•V) لسـنةV I • بجمهوريـة مصـر العربيـة

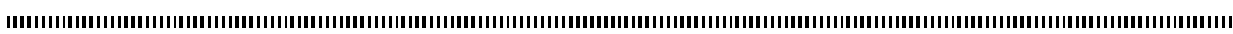
1 - مريم وحيد مخيمر : قراءة فى قانون الجمعيات الأهلية الجيد ( متابعات

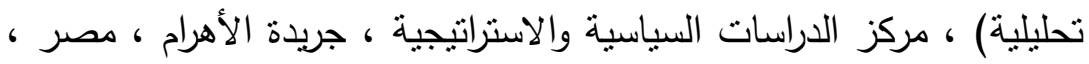

$$
\cdot r+19
$$

r ا - مؤسسة ماعت للساحم والتتمية وحقوق الإنسان : مسودة اللائحة التفيذية لقانون

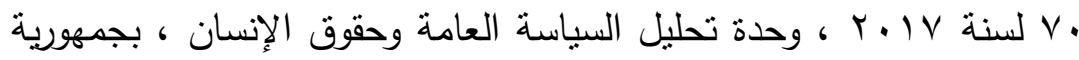

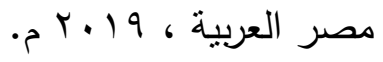

